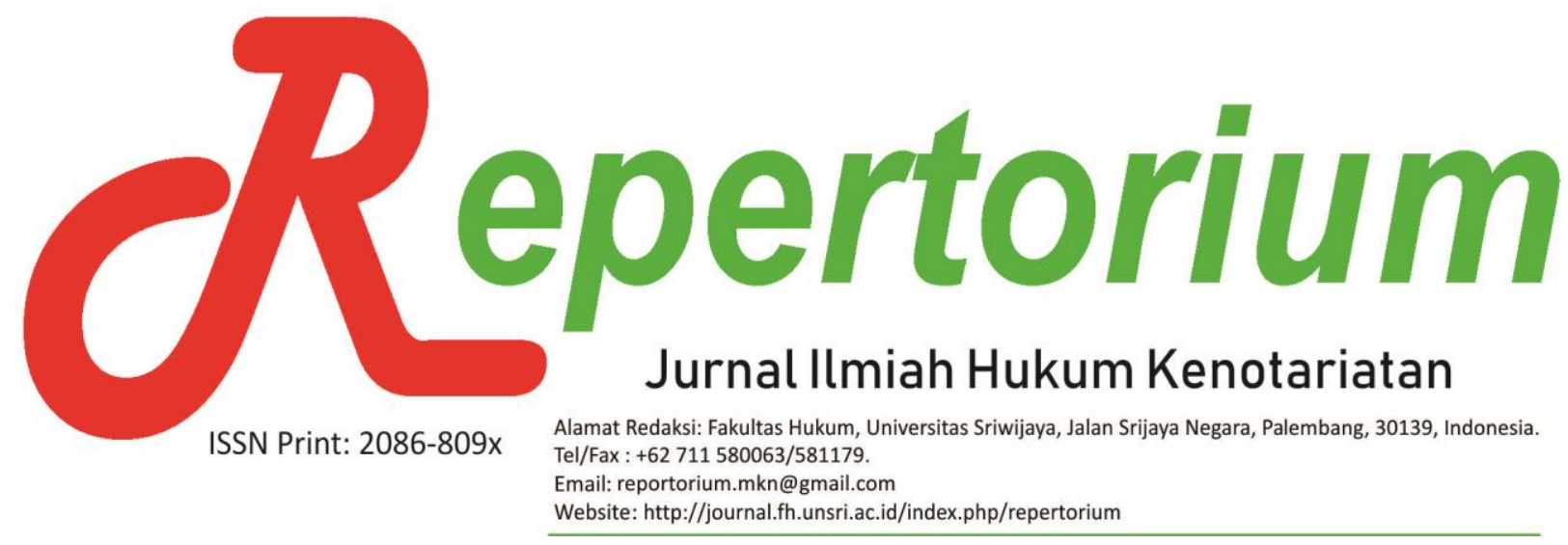

\title{
TANGGUNG JAWAB HUKUM PELAKSANA PEKERJAAN KONSTRUKSI TERHADAP KEGAGALAN PEKERJAAN KONSTRUKSI DAN BANGUNAN
}

\begin{abstract}
Adeline Evelina*
Abstrak: Perjanjian bangun bagi adalah perjanjian yang lahir akibat dari kesepakatan para piha, dimana kesepakatan yang lahir tersebut adalah kesepakatan antara pemilik lahan dan pihak kedua, pengembang. Perjanjian bangun bagi merupakan perjanjian yang menganut asas kebebasan berontrak yang diatur di dalam Pasal 1320 KUHPerdata. Di dalam perjanjian tersebut para pihak berharap memperoleh hak sesuai dengan perjanjian dimana pihak kedua diberi hak untuk mengerjakan sebidang lahan yang biasanya berbentuk sebuah bangunan, dengan syarat bahwa keuntungan dibagi menjadi dua: bagi pemilik lahan dan pengembang/developer. Dalam proses pelaksanaan kesepakatan pembagian kerja, akan ada banyak masalah antara kedua belah pihak, salah satunya yaitu tentang perbuatan melawan hukum. Hasil penelitian menunjukkan bahwa perbuatan melawan hukum yang dilakukan oleh pemilik lahan kepada pengembang/developer merupakan suatu pebuatan yang menimbulkan kerugian bagi kedua belah pihak sehingga masing-masing pihak harus bertanggung jawab untuk menyelesaikan kewajibannya sesuai dengan apa yang tertulis di dalam perjanjian. Adapun upaya yang ditempuh dalam menyelesaikan sengketa yang terjadi adalah melalui gugatan di pengadilan. Gugatan di pengadilan tersebut melibatkan notaris yang berperan sebagai pihak yang turut tergugat, notaris dimasukkan di dalam gugatan adalah untuk melengkapi subjek/para pihak di dalam gugatan, karena suatu gugatan tidak lengkap rumusan subjeknya akan menjadi gugatan error in persona.
\end{abstract}

Kata kunci: Perjanjian; Sengketa.

* Magister Kenotariatan Fakultas Hukum Universitas Sriwijaya

\section{LATAR BELAKANG}

Menurut hukum perjanjian Indonesia suatu perjanjian adalah suatu perbuatan dengan mana satu orang atau lebih mengikatkan dirinya terhadap satu orang lain/lebih (Pasal 1313 BW). ${ }^{1}$

Dalam melakukan suatu perjanjian atau melaksanakan kontrak ada pula hal yang sangat penting yang harus dan wajib

1 Lista Kuspriatni, 1998, Aspek Hukum dan Ekonomi, Jakarta: PT Intermasa, hlm. 1 
diketahui yaitu syarat sahnya suatu perjanjian, karena di dalam melakukan suatu perjanjian atau kontrak para pihak yang melakukan kesepakatan mesti memenuhi syarat sahnya perjanjian tersebut, hal itu dilakukan agar suatu Perjanjian dapat menjadi sah dan mengikat para pihak.

Pasal 1338 ayat (1) KUH Perdata menyatakan bahwa semua kontrak (perjanjian) yang dibuat secara sah berlaku sebagai undang-undang bagi mereka yang membuatnya. Di dalam pasal ini dapat disimpulkan adanya asas kebebasan berkontrak (Contract Vrijheid Beginsel), akan tetapi kebebasan ini dibatasi oleh hukum yang sifatnya memaksa (Dwingen), sehingga para pihak yang membuat perjanjian harus menaati hukum yang sifatnya memaksa (Dwingenrecht). Suatu perjanjian tidak dapat ditarik kembali selain dengan sepakat kedua belah pihak, atau karena alasan-alasan yang oleh undangundang dinyatakan cukup untuk itu. Perjanjian tidak hanya mengikat untuk halhal yang dengan tegas dinyatakan didalamnya, tetapi juga untuk segala sesuatu yang menurut sifat perjanjian, diharuskan oleh kepatutan, kebiasaan atau undang-undang. Suatu perjanjian tidak diperbolehkan membawa kerugian kepada pihak ketiga. $^{2}$

Dalam Perjanjian Bagi Bangun yang dibuat bersamaan dengan Pelaksanaan Pekerjaan Konstruksi, pada umumnya dibuat di hadapan Notaris yang dilakukan antara Pemegang Hak Atas Tanah atau Pengguna Jasa Konstruksi dengan Pengguna Hak Atas Tanah atau Penyedia Jasa Konstruksi (Pengembang/Developer).

2 Ibid, hlm.3
Pada prinsipnya dalam perjanjian bagi bangun, pemegang hak atas tanah menukar sebagian luas tanahnya untuk membayar bangunan yang dibangunkan oleh pengguna hak atas tanah dan sebaliknya pengguna hak atas tanah melakukan pembangunan gedung, rumah, atau toko untuk pemegang hak atas tanah sebagai pembayaran pemberian sebagian hak atas tanah dari pemegang hak atas tanah. Sehingga hak atas tanah yang dimiliki oleh si pemegang hak atas tanah dapat beralih atau dialihkan kepada pihak lain yang disini adalah pengguna hak atas tanah tersebut. ${ }^{3}$ Secara de facto, pemegang hak atas tanah juga dapat meminta sejumlah pembayaran tidak seluruhnya dengan bangunan, tetapi dapat juga dikombinasikan dengan sejumlah uang. Hal ini sesuai kesepakatan yang akan dituangkan di dalam akta notaris. Kedudukan notaris dalam pembuatan perjanjian bangun bagi haruslah menjelaskan isi perjanjian tersebut dengan detail kepada pihak-pihak yang terkait dalam perjanjian bangun bagi, yaitu secara adil tentang untung dan rugi maupun resiko dari perjanjian bangun bagi, notaris berkewajiban menjelaskan kepada pihakpihak yang terkait dalam perjanjian bangun bagi secara jujur, saksama, mandiri, tidak berpihak, dan menjaga kepentingan pihak yang terkait tentang untung dan rugi maupun resiko dari perjanjian bangun bagi,

$$
\text { Pelaksanaan }
$$

Pekerjaan

Pembangunan Konstruksi dilaksanakan dengan dasar kontrak kerja konstruksi yang telah disepakati sebelumnya. Pelaksanaan dan pengawasan pekerjaan konstruksi dalam Pasal 28 ayat 1 Peraturan Pemerintah Nomor 29 Tahun 2000 tentang

\footnotetext{
${ }^{3}$ Urip Santoso, 2015. Perolehan Hak Atas Tanah. Jakarta: PT. Kharisma Putra Utama, hlm. 31.
} 
Penyelenggaraan Jasa Konstruksi meliputi pelaksanaan fisik, pengawasan, ujicoba, dan penyerahan hasil akhir pekerjaan. Hasil akhir dari pekerjan meliputi hasil tahapan pekerjaan, hasil peyerahan, dan hasil penyerahan pertama dan hasil penyerahan akhir secara tepat biaya, tepat mutu, dan tepat waktu. Tidak sedikit kasus dari penyerahan akhir pekerjaan konstruksi, ternyata bangunan tidak berfungsi, baik secara keseluruhan maupun sebagian dari segi tehnis, manfaat, keselamatan, dan kesehatan kerja, dan atau keselamatan umum sebagai akibat kesalahan Penyedia Jasa (Pengembang) atau yang disebut dengan Kegagalan Pekerjaan Kontruksi dan Kegagalan Bangunan.

Adapun contoh kasus dari kegagalan pekerjaan pembangunan konstruksi dalam perjanjian bagi bangun adalah mengenai akta perjanjian bangun bagi pekerjaan konstruksi yang dilakukan oleh Tuan Darwin Herijanto selaku Pihak Penggugat sebagai penyedia jasa atau developer perorangan (yang disii juga terlibat adalah pekerja bangunan dati pihak developer) dengan sembilan bersaudara dari almarhum H. Tjek Dencik dan PT. Sumber Alfaria Trijaya, Tbk selaku pihak tergugat atau pengguna jasa konstruksi atau pemilik tanah. ${ }^{4}$ Dimana pihak kedua selaku tergugat tersebut melakukan perbuatan melawan hukum terhadap apa yang diperjanjikan oleh pihak penggugat dan tergugat disini adalah mengenai perjanjian pembangunan rumah toko (ruko) yang sebelumnya telah diperjanjian untuk dibagi bangun antara pihak tergugat dan penggugat secara adil yang telah disebutkan di dalam akta notaris. Namun di dalam

\footnotetext{
${ }^{4}$ Kasus dapat dilihat di dalam putusan pengadilan negeri palembang No.52/pdt/G/2012/PN.PLG
}

perjalanan penyelesaian pembangunan ruko pihak penggugat selalu diintimidasi dan dilakukan pemukulan oleh pihak tergugat dan ruko yang seharusnya diselesaikan menjadi terhambat begitu pula ruko yang sudah selesai yang di dalam akta notaris seharusnya menjadi milik pihak penggugat disewakan oleh pihak tergugat kepada PT. Sumber Alfaria Trijaya, Tbk tanpa sepengetahuan pihak penggugat sehingga menimbulkan kegagalan pekerjaan konstruksi dan bangunan yang merugikan pihak penggugat. Oleh karena hal tersebut pihak pertama mengajukan gugatannya kepada Pengadilan Negeri untuk menuntut ganti kerugian dan pembatalan atas perjanjian tersebut.

Gugatan yang diajukan oleh pihak pertama tersebut mendapatkan putusan No.52/Pdt/G/2012/PN.PLG dimana hakim memutuskan untuk menghukum pihak tergugat yang melakukan perbuatan melawan hukum, dimana gugatan tersebut dikabulkan sebagian.

Kegagalan pembangunan pekerjaan konstruksi dan bangunan biasanya akan muncul pada saat penyerahan akhir pekerjaan konstruksi dimana penyelenggaraan pekerjaan konstruksi telah selesai dan pembangunan telah selesai namun juga tidak menutup kemungkinan kegagalan pekerjaan konstruksi dan kegagalan bangunan terjadi pada saat dalam proses pelaksanaan pembangunan. 

Berdasarkan uraian diatas maka penulis menyusun tesis dengan judul Tanggung Jawab Hukum Pelaksana Pekerjaan Konstruksi Terhadap Kegagalan Pekerjaan Konstruksi dan Bangunan

Berdasarkan uraian di atas ada beberapa permasalahan yang dapat dibahas dalam tesis ini, yaitu:

1. Bagaimana hak dan kewajiban penyedia jasa konstruksi (pengembang/developer) dan pengguna jasa kontruksi terhadap perjanjian bangun bagi dalam pelaksanaan pekerjaan konstruksi yang dibuat di hadapan notaris?

2. Bagaimana penyelesaian sengketa oleh penyedia jasa konstruksi (pengembang/developer) dan pengguna jasa konstruksi terhadap kegagalan pekerjaan konstruksi dan bangunan yang timbul atas perbuatan melawan hukum dalam suatu perjanjian bangun bagi yang dibuat di hadapan notaris?

\section{Metode Penelitian}

Permasalahan yang akan dibahas di dalam penelitian ini merupakan penelitian Hukum Normatif, karena penelitian ini merupakan penelitian kepustakaan atau studi dokumen yang dilakukan atau ditujukan hanya pada peraturan-peraturan yang tertulis atau badan hukum yang lain ${ }^{5}$. Dengan demikian penelitian ini meliputi penelitian terhadap asas-asas hukum, sumber-sumber hukum, peraturan perundang-undangan yang terkait dengan tanggung jawab hukum pelaksana pekerjaan konstruksi terhadap kegagalan pekerjaan konstruksi dan kegagalan

\footnotetext{
${ }^{5}$ Soerjono Soekanto ,Sri Mamudji.1985. Penelitian Hukum Normatif Suatu Tinjauan Singkat. Jakarta : CV Rajawali. hlm.23.
}

bangunan dalam suatu perjanjian bagi bangun.

Penelitian ini melakukan pendekatan perundang-undangan (statute approach) yang dititk beratkan pada ketentuan yang terdapat dalam UndangUndang Nomor 18 Tahun 1999 tentang Jasa Konstruksi, Peraturan Pemerintah Nomor 29 Tahun 2000 tentang Jasa Konstruksi, Kitab Undang-Undang Hukum Perdata, Undang-Undang Jabatan Notaris, Kode Etik Notaris dan peraturan perundang-undangan terkait lainnya.

Teknik Pengumpulan sumber Bahan Hukum yang digunakan dalam penelitian ini adalah: Studi Dokumen, untuk mengumpulkan data sekunder guna pelajari kaitannya dengan permasalahan yang diajukan. Bahan Hukum ini diperoleh melalui studi kepustakaan dengan cara menyeleksi, dan mengklasifikasi bahanbahan hukum yang relevan. Studi dokumentasi dilakukan melalui penelusuran kepustakaan (library research)

Teknik Analisis Bahan Hukum merupakan suatu proses mengorganisasikan dan mengurutkan data ke dalam pola, kategori dan uraian dasar sehingga dapat ditentukan tema dan dapat dirumuskan suatu hipotesis kerja seperti yang disarankan.

Mengingat sifat penelitian maupun objek penelitian, maka semua bahan hukum yang diperoleh akan dianalisa secara deskriftif kualitatif, dengan cara mengumpulkan Bahan Hukum dipisahpisahkan menurut kategori masing-masing dan kemudian dideskripsikan dalam uraian yang mendalam sehingga diperoleh jawaban terhadap permasalahan dalam penelitian. Analisa dilakukan dengan menggunakan penafsiran hukum berupa 

penafsiran otentik (resmi) dari pembentuk undang-undang dan penafsiran sistematis dengan cara mengaitkan isi norma pengaturan hukum yang satu dengan yang lain.

\section{ANALISIS DAN DISKUSI}

Hak dan Kewajiban Penyedia Jasa Konstruksi dan Pengguna Jasa Konstruksi dalam Pelaksanaan Perjanjian Bangun Bagi yang Dibuat di Hadapan Notaris

Dalam setiap perjanjian atau kontrak yang melibatkan dua pihak pastilah menimbulkan hak dan kewajiban atau tugas dan kewenangan bagi para pihak. Hak bagi satu pihak merupakan kewajiban (prestasi) yang harus dilaksanakan oleh pihak lainnya. Demikian pula dalam kontrak kerja konstruksi terdapat dua pihak yaitu pengguna jasa dan penyedia jasa konstruksi, yang mana masing-masing pihak memiliki hak dan kewajiban yaitu:

Hak Penyedia Jasa Konstruksi sebagai developer terhadap perjanjian bagi bangun dalam pelaksanaan pekerjaan konstruksi yang dibuat di hadapan notaris:

1) Setelah bangunan-bangunan tersebut selesai dibangun, maka beberapa bangunan diantaranya dengan sendirinya merupakan hak dari pengguna jasa konstruksi sesuai yang telah diperjanjikan.

2) Bangunan yang dibangun diatas tanah pihak penyedia jasa konstruksi dibangun sesuai dengan keinginan pengguna jasa konstruksi (developer).

Kewajiban Penyedia Jasa Konstruksi sebagai developer terhadap perjanjian bagi bangun dalam pelaksanaan pekerjaan konstruksi yang dibuat di hadapan notaris:
1. Membangun bangunan diatas tanah penyedia jasa konstruksi sesuai dengan apa yang telah disepakati di hadapan notaris.

2. Bangunan yang dibangun diatas tanah milik pengguna jasa konstruksi harus berdiri sesuai dengan kesepakatan sebelumnya yang di dalamnya tertulis mengenai bahan, alat, dan jangka waktu penyelesaian bangunan tersebut.

Hak Pengguna Jasa Konstruksi sebagai developer terhadap perjanjian bagi bangun dalam pelaksanaan pekerjaan konstruksi yang dibuat di hadapan notaris:

1. Bangunan yang dibangun diatas tanah milik pengguna jasa konstruksi harus selesai sesuai dengan jangka waktu yang diperjanjikan.

2. Bentuk bangunan yang dibangun diatas tanah milik pengguna jasa konstruksi harus sesuai dengan yang diperjanjikan.

Kewajiban Pengguna Jasa Konstruksi sebagai developer terhadap perjanjian bagi bangun dalam pelaksanaan pekerjaan konstruksi yang dibuat di hadapan notaris:

1) Memberikan izin, hak, dan kuasa kepada pihak penyedia jasa untuk mendirikan bangunan diatas tanah miliknya.

2) Menyerahkan beberapa bangunan rumah kepada pihak developer dengan membuat atau menanda tangani segala akte-akte/surat-surat yang berhubungan dengan penyerahan atau penjualannya.

Suatu kontrak konstruksi yang dibuat harus telah memenuhi syarat - syarat yang sah dan asas - asas suatu kontrak, tetapi di dalam pelaksanaannya tidak menutup kemungkinan untuk terjadinya kegagalan pekerjaan konstruksi dan 

bangunan (Building Failure). Dalam pekerjaan konstruksi bangunan sering ditemukannya kegagalan pekerjaan konstruksi dan bangunan yang dapat diakibatkan oleh pihak penyedia jasa atau pengguna jasa.

\section{Dalam Pasal 31 Peraturan}

Pemerintah Nomor 29 Tahun 2000 tentang Penyelenggaraan Jasa Konstruksi menyatakan bahwa yang dimaksud dengan kegagalan konstruksi adalah keadaan hasil pekerjaan konstruksi yang tidak sesuai dengan spesifikasi pekerjaan sebagaimana disepakati dalam kontrak kerja konstruksi baik sebagian maupun keseluruhan sebagai akibat dari kesalahan dari pengguna jasa atau penyedia jasa.

Kegagalan konstruksi ${ }^{6}$ adalah hasil pekerjaan yang tidak sesuai dengan spesifikasi teknis baik sebagian ataupun keseluruhan yang diakibatkan oleh kesalahan pihak penyedia jasa atau pengguna jasa. Menurut waktu kejadiannya, kegagalan bangunan dan kegagalan konstruksi itu berbeda. Kegagalan konstruksi terjadi selama masa konstruksi, dimana bangunannya belum selesai. Sedangkan kegagalan bangunan terjadi setelah serah terima akhir pekerjaan antara pihak penyedia jasan dan pengguna jasa. Didalam peraturan pemerintah, kedua kegagalan tersebut diakibatkan oleh kesalahan pihak penyedia jasa atau pengguna jasa.

Kegagalan bangunan dapat disebabkan oleh faktor kesalahan manusia itu sendiri. Kesalahan manusia itu dapat diakibatkan dari ketidaktahuan atau kesalahan kinerja (kecerobohan dan kelalaian). Ketidaktahuan dapat diakibatkan dari kurangnya pelatihan, pendidikan dan pengalaman. Kesalahan kinerja (kecerobohan dan kelalaian) termasuk salahnya dalam perhitungan dan tidak terperinci, tidak benar dalam membaca gambar dan spesifikasi dan cacat konstruksi. Walaupun demikian, konsultan tersebut harus merencanakan segala sesuatunya dengan baik, sehingga mendapatkan hasil yang maksimal juga.

Mengacu pada kasus diatas maka kegagalan pekerjaan konstruksi dan bangunan ini merupakan tindakan Perbuatan Melawan Hukum meskipun di dalamnya terdapat suatu kejadian bangunan menjadi terbengkalai selama kurang lebih 6 (enam) tahun dari waktu yang diperjanjikan dan hal ini dapat dikategorikan sebagai perbuatan wanprestasi tetapi karena di dalam penyelesaiannya terdapat intimidasi dari pihak pengguna jasa konstruksi kepada pihak penyedia jasa konstruksi dalam perjanjian bagi bangun tersebut maka hal ini menjadi kesalahan yang disebabkan oleh Perbuatan Melawan Hukum yang dilakukan oleh pihak tergugat.

Cidera janji (Wanprestasi), merupakan suatu keadaan tidak terlaksananya suatu perjanjian dikarenakan kesalahan/kelalaian para pihak atau salah satu pihak. Bentuk Cidera janji (Wanprestasi) berupa:

1. Tidak melaksanakan apa yang disanggupi akan dilakukan;

2. Melaksanakan apa yang diperjanjikan tapi tidak sempurna;

3. Melaksanakan apa yang dijanjikan tapi tidak tepat waktu; dan

4. Melaksanakan sesuatu yang menurut perjanjian tidak boleh dilakukan.

Perbuatan melawan hukum (onrechtmatige daad), merupakan setiap 
perbuatan melanggar hukum yang menimbulkan kerugian pada orang lain, mewajibkan pembuat yang bersalah untuk mengganti kerugian sebagaimana dinyatakan dalam Pasal 1365 KUHPerdata.

Melawan hukum secara sempit dapat diartikan sebagai melanggar hukum atau undang-undang. Namun, pengertian tersebut telah lebih dinamis. Hal mana pelanggaran terhadap norma kepatutan, keadilan atau kebiasaan di masyarakat juga dapat dikualifikasikan sebagai perbuatan melawan hukum, sepanjang perbuatan tersebut mengakibatkan kerugian bagi pihak lain. Oleh karena itu perbuatan tersebut haruslah berupa kerugian yang ditimbulkan karena disebabkan karena perbuatan yang melawan hukum, yang antara lain:

1) Melanggar hak orang lain;

2) Bertentangan dengan kewajiban hukum si pelaku;

3) Bertentangan dengan kesusilaan; dan

4) Bertentangan dengan kepentingan umum.

5) Kerugian dan perbuatan itu harus ada hubungannya yang langsung;

6) Kerugian itu disebabkan karena kesalahan pembuat.

7) Kesalahan adalah apabila pada pelaku ada kesengajaan atau kealpaan (kelalaian)

Selain hal-hal di atas, suatu perbuatan melawan hukum dapat tidak hanya terdiri atas satu perbuatan, tetapi juga dalam tidak berbuat sesuatu. Sebagaimana KUHPerdata menentukan bahwa setiap orang tidak saja bertanggungjawab terhadap kerugian yang disebabkan karena perbuatannya sendiri, tetapi juga terhadap kerugian yang ditimbulkan karena perbuatan orang-orang yang ditanggungnya, atau karena barang-barang yang berada dibawah pengawasannya serta terdapat kesengajaan yang timbul dari tindakan intimidasi dari pihak tergugat maka kasus ini dikategorikan sebagai kasus Perbuatan Melawan Hukum.

Maka dari itu karena hal tersebut bertentangan dengan kewajiban hukum dari pihak tergugat untuk memberikan tanahnya agar diselesaikan pembangunan ruko berdasarkan perjanjian bagi bangun yang dibuat dengan pihak penggugat dan juga terdapat pelanggaran terhadap hak orang lain untuk menyelesaikan pembangunan tersebut

Dalam setiap pembangunan yang dilaksanakan setiap tanggung jawab seharusnya akan dibebankan kepada penyedia jasa atau pengembang/developer baik perseorangan atau badan hukum. Kegagalan pekerjaan konstruksi dan bangunan di suatu pembangunan biasanya dikaitkan dengan pihak-pihak yang memiliki cara untuk memilih langkahlangkah mengamankan dan menyelamatkan orang-orangnya yang terlibat dari pada mengamankan atau menyelesaikan masalah-masalah itu sendiri. Tidak jarang kondisi alamlah yang disalahkan dalam kegagalan pekerjaan konstruksi dan bangunan untuk menyelamatkan kecerobohan dan kelalaian manusiamanusia yang seharusnya bertanggung jawab dalam kegagalan konstruksi tersebut.

Padahal peraturan-peraturan yang dibuat oleh pemerintah dan perundangundangan yang baik telah mengatur dengan baik sebab dan akibat yang mesti dipertanggungjawabkan oleh para pihak yang melakukan kesalahan dimana semua pihak yang terlibat seharusnya sudah mulai menyadari pentingnya mengikuti aturan Undang-Undang. 
Penyelesaian Sengketa yang Terjadi Akibat Kegagalan Pekerjaan Konstruksi dan Bangunan dalam Perjanjian Bangun Bagi yang dilakukan oleh Penyedia jasa Konstruksi dan Pengguna Jasa Konstruksi di Hadapan Notaris

Seorang notaris senantiasa dibutuhkan oleh masyarakat pada umumnya, khususnya bagi masyarakat yang telah memiliki kesadaran hukum yang baik tentang diperlukannya kepastian hukum dalam setiap perbuatan hukum yang dilakukannya, dengan menuangkan dalam suatu alat bukti otentik, yakni akta notaris. Hal tersebut melahirkan kepercayaan masyarakat terhadap notaris karena akta yang dibuatnya, yang menyebabkan jabatan notaris sering pula disebut dengan jabatan kepercayaan, yaitu kepercayaan pemerintah sebagai instansi yang mengangkat dan memberhentikan notaris sekaligus pula kepercayaan masyarakat sebagai pengguna jasa notaris.

Notaris seyogyanya berada dalam ranah pencegahan dalam (preventif) terjadinya masalah hukum melalui akta otentik yang dibuatnya sebagai alat bukti yang sempurna di pengadilan. Akta otentik pada hakikatnya memuat kebenaran formal sesuai dengan apa yang diberitahukan para pihak kepada Notaris. Notaris mempunyai kewajiban untuk menjelaskan secara terperinci bahwa apa yang termuat dalam akta Notaris sungguh-sungguh telah dimengerti dan sesuai dengan kehendak para pihak yaitu dengan cara membacakannya sehingga menjadi jelas isi akta Notaris serta memberikan akses terhadap informasi termasuk akses terhadap peraturan perundang-undangan yang terkait bagi para pihak, penandatangan akta. Dalam hal ini notaris sebagai pihak yang bertujuan mencapai keadilan dalam pembuatan akta otentik di depan para pihak yang melakukan perjanjian. Notaris dalam menjalankan jabatannya berperan secara tidak memihak (unpartiality) dan bebas (Independency) ${ }^{7}$. Sehingga dalam keabsahan akta yang telah dibuat berati telah menjadi persetujuan kedua belah pihak yang membuat perjanjian sehingga apabila di kemudian hari terjadi perselisihan notaris berada sebagai konsultan atau penengah diantara keduanya.

Keberadaan akta autentik yang dibuat oleh notaris digunakan untuk melindungi dan menjamin hak dan kewajiban dari para pihak yang mengadakan perjanjian sehingga apabila dikemudian hari ada salah satu pihak yang melanggarnya maka dapat dikenakan sanksi atau hukuman. Hal inilah yang membuat masyarakat percaya, bahwa notaris dapat menuangkan kehendak mereka kedalam bentuk akta notaris serta memberikan perlindungan hukum. ${ }^{8}$

Kehadiran Notaris sebagai pejabat umum yang berwenang mempunyai peranan penting dalam proses penyelesaian sengketa, akta perdamaian merupakan alat bukti tertulis terkuat dan terpenuh serta memberi sumbangan nyata bagi penyelesaian perkara secara murah dan cepat. Akta perdamaian dibuat karena dikehendaki oleh pihak yang berkepentingan untuk memastikan hak dan kewajiban para pihak demi kepastian, ketertiban, dan perlindungan hukum bagi pihak yang berkepentingan.

\footnotetext{
${ }^{7}$ Herlin Budiono, 2007, Kumpulan Tulisan Hukum Perdata di Bidang Kenotariatan, Bandung: Citra Aditya Bakti. hlm. 22

${ }^{8}$ Ibid, hlm. 10
} 
Dalam penyelesaian sengketa yang terjadi terhadap kegagalan pekerjaan konstruksi dan bangunan dalam suatu perjanjian bagi bangun yang dilakukan oleh penyedia jasa konstruksi dan pengguna jasa konstruksi, Sengketa dapat diselesaikan melalui cara-cara formal yang berkembang menjadi proses ajudikasi yang terdiri dari proses melalui pengadilan dan arbitrase atau cara informal yang berbasis pada kesepakatan pihak-pihak yang bersengketa melalui negosiasi dan mediasi. ${ }^{9}$

Di dalam kasus ini yaitu murni Perbuatan Melawan Hukum, dikatakan Perbuatan Melawan Hukum karena Pihak Pemilik Tanah menghambat penyelesaian bangunan dengan melakukan intimidasi yaitu berupa pemukulan dan menghalangi pihak pekerja masuk ke dalam lingkungan tanah untuk menyelesaikan bangunan. Apabila pihak pemilik tanah hanya tidak mau menyerahkan tanah tersebut kepada pihak developer untuk diselesaikan tanpa melakukan intimidasi berupa pemukulun dan lain sebagainya maka hal itu baru dapat disebut dengan perbuatan wanprestasi yang dilakukan oleh pihak pemilik tanah kepada pihak developer karena tidak mau menyerahkan tanah yang telah diperjanjikan untuk dibangun ruko.

Menurut Retnowulan Sutantio dan Iskandar Oeripkartawinata dalam bukunya "Hukum Acara Perdata Dalam Teori dan Praktek", dalam praktik perkataan Turut Tergugat dipergunakan bagi orang-orang yang tidak menguasai barang sengketa atau tidak berkewajiban untuk melakukan sesuatu, hanya demi lengkapnya suatu

9 Rachmadi Usman I , 2003, Pilihan Penyelesaian Sengketa di Luar Pengadilan. Bandung: PT. Citra Aditya Bakti. hal 3. gugatan harus diikutsertakan. ${ }^{10}$ Mereka dalam petitum hanya sekedar dimohonkan agar tunduk dan taat terhadap putusan Hakim.

Jadi, apabila seorang notaris berkedudukan sebagai Turut Tergugat dalam suatu gugatan, ia hanya berkedudukan sebagai pelengkap saja. Notaris tersebut dijadikan Turut Tergugat agar gugatan menjadi lengkap, sehingga Turut Tergugat dapat dimohonkan agar tunduk dan taat terhadap putusan, padahal pihak yang berkepentingan secara langsung adalah Penggugat dan Tergugat.

Dalam mewujudkan keadilan hukum dalam menyelesaikan kasus hukum yang terjadi di masyarakat, hakim harus menggunakan metode pemikiran yuridis dengan karakteristik sebagai berikut: ${ }^{11}$

1. Argumen (legal reasoning), yang berusaha mewujudkan konsistensi dalam aturan hukum dan keputusan hukum. Dasar pemikiran adalah keyakinan bahwa hukum harus sama untuk semua orang.

2. Penalaran dialektis terjadi dalam penalaran hukum, yang menimbang hasil yang berlawanan, baik dalam perdebatan tentang pembuatan undangundang atau dalam proses mempertimbangkan pandangan dan fakta yang dipresentasikan oleh para pihak dalam proses peradilan.

10 Retnowulan Sutantio. 1989. Hukum Acara Perdata dalam Teori dan Praktek. Jakarta: Mandar Maju. Hlm. 2

11 Edy Lisdiyono. Improving Legal Argument Critically in the Litigation Mechanism in Indonesia. Sriwijaya Law Review. Fakultas Hukum. Palembang: Universitas Sriwijaya. HIm. 67 


\section{KESIMPULAN DAN SARAN}

Di dalam praktik kegiatan pekerjaan konstruksi dalam suatu perjanjian bangun bagi yang dilakukan oleh pihak penyedia jasa (developer) dengan pihak pengguna jasa konstruksi, kegagalan pekerjaan konstruksi dan bangunan adalah hal yang seringkali ditemui. Kali ini kegagalan pekerjaan konstruksi dan bangunan yang terjadi adalah tentang terdapatnya suatu Perbuatan Melawan Hukum yang dengan sengaja dibuat oleh Pengguna Jasa Konstruksi dengan cara melakukan intimidasi oleh pihak bersangkutan berupa pemukulan dan kegiatan pembangunan yang dihalang-halangi serta pihak pengguna jasa konstruksi memakai hak milik bangunan dari penyedia jasa konstruksi yang seharusnya milik dari penyedia jasa konstruksi. Sehingga, pembangunan konstruksi rumah toko (ruko) yang diperjanjikan di dalam akta perjanjian bagi bangun yang dibuat di hadapan notaris menjadi terbengkalai dan bangunan rumah toko (ruko) sebagian menjadi tidak terselesaikan. Maka dari itu, masing-masing pihak harus memenuhi hak dan kewajiban di dalam perjanjian bangun bagi yang dilakukan oleh pihak penyedia jasa dan pengguna jasa konstruksi sejak awal dibuatnya perjanjian tersebut guna untuk dapat bertanggung jawab penuh terhadap kegagalan pekerjaan konstruksi dan bangunan yang disebabkan oleh kelalaian yang timbul diantara kedua belah pihak baik dari Pengguna Jasa Konstruksi atau Penyedia Jasa Konstruksi.

Kedudukan notaris dalam pembuatan perjanjian bangun bagi adalah untuk menjelaskan isi perjanjian tersebut dengan detail kepada pihak-pihak yang terkait dalam perjanjian bangun bagi, yaitu tentang untung dan rugi maupun resiko dari perjanjian bangun bagi guna untuk mencapai keadilan bagi para pihak, notaris berkewajiban menjelaskan kepada pihakpihak yang terkait dalam perjanjian bangun bagi secara jujur, saksama, mandiri, tidak berpihak, dan menjaga kepentingan pihak yang terkait tentang untung dan rugi maupun resiko dari perjanjian bangun bagi, hal ini juga dilakukan untuk mencapai kepastian hukum bagi para pihak yang melakukan perjanjian. Sehingga apabila terjadi kegagalan pekerjaan konstruksi dan bangunan, notaris dapat bertindak sebagai mediator/konsultan dalam penyelesaian masalah sengketa yang terjadi antara Pihak Penyedia Jasa Konstruksi (developer) dan Pengguna Jasa Konstruksi. Kedudukan Notaris dari permasalahan yang terjadi di dalam kasus ini yaitu dapat menjadi mediator apabila akan diselesaikan secara non-litigasi dan bila melewati jalan litigasi Notaris dapat menjadi pihak Turut Tergugat agar gugatan menjadi lengkap, sehingga Turut Tergugat dapat dimohonkan agar tunduk dan taat terhadap putusan, padahal seharusnya pihak yang berkepentingan secara langsung adalah Pihak Penggugat dan Pihak Tergugat.

Saran, di dalam pembuatan akta perjanjian bagi bangun yang dibuat di hadapan notaris hendaknya membuat klausula-klausula baru dalam perjanjian tersebut yang menyebutkan kejadiankejadian yang akan timbul di kemudian hari tidak hanya tentang wanprestasi saja tetapi juga tentang Perbuatan Melawan Hukum yang bisa saja timbul yang dapat merugikan salah satu pihak yang membuat perjanjian.

Notaris juga dalam menjalankan tugas dan wewenangnya harus lebih teliti agar akta tersebut dapat menjadi akta yang 
dapat memiliki kekuatan apabila dibawa ke dalam kasus sengketa yang terjadi antara pihak pengguna jasa konstruksi dan penyedia jasa konstruksi.

\section{DAFTAR PUSTAKA}

\section{Buku}

Budiono, Herlin. 2007. Kumpulan Tulisan Hukum Perdata di Bidang Kenotariatan, Bandung: Citra Aditya Bakti.

Kuspriatni, Lista. 1998. Aspek Hukum dan Ekonomi. Jakarta: PT Intermasa.

Santoso, Urip. 2010. Hukum Agraria dan Perolehan Hak Atas Tanah. Jakarta: Kencana Premadina.

Soekanto, Soerjono dan Sri Mamudji. 1985. Penelitian Hukum Normatif Suatu Tinjauan Singkat. Jakarta: CV. Rajawali.

Sutantio, Retnowulan. 1989. Hukum Acara Perdata dalam Teori dan Praktek. Jakarta: Mandar Maju.

Usman I, Rachmadi. 2003. Pilihan Penyelesaian Sengketa di Luar Pengadilan, Bandung: PT. Citra Aditya Bakti.

\section{Jurnal}

Edy Lisdiyono. Improving Legal Argument Critically in the Litigation Mechanism in Indonesia. Sriwijaya Law Review. Fakultas Hukum. Palembang: Universitas Sriwijaya.

\section{Peraturan Perundangan}

Peraturan Pemerintah Nomor 29 Tahun 2000

\section{Website}

Kedudukan Notaris sebagai Turut Tergugat. 2015. http://www.hukumonline.com/klinik /detail/lt4f2a062695e26/kedudukannotaris-sebagai-turut-tergugat 